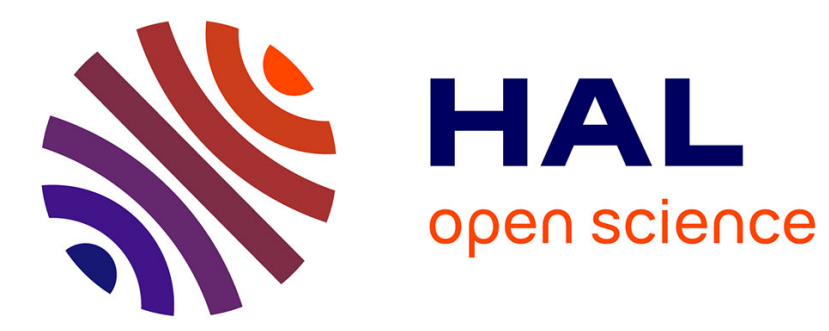

\title{
The changing landscape of ecological networks
}

Ruppert Vimal, Raphael Mathevet, John Thompson

\section{To cite this version:}

Ruppert Vimal, Raphael Mathevet, John Thompson. The changing landscape of ecological networks. Journal for Nature Conservation, 2012, 20, pp.49-55. 10.1016/j.jnc.2011.08.001 . hal-02456105

\section{HAL Id: hal-02456105 \\ https://hal-univ-tlse2.archives-ouvertes.fr/hal-02456105}

Submitted on 27 Jan 2020

HAL is a multi-disciplinary open access archive for the deposit and dissemination of scientific research documents, whether they are published or not. The documents may come from teaching and research institutions in France or abroad, or from public or private research centers.
L'archive ouverte pluridisciplinaire HAL, est destinée au dépôt et à la diffusion de documents scientifiques de niveau recherche, publiés ou non, émanant des établissements d'enseignement et de recherche français ou étrangers, des laboratoires publics ou privés. 


\title{
The changing landscape of ecological networks
}

\author{
Ruppert Vimal, Raphael Mathevet*, John D. Thompson \\ UMR 5175 Centre d'Ecologie Fonctionnelle et Evolutive, CNRS, 1919 route de Mende, 34293 Montpellier cedex 5, France
}

\section{A R T I C L E I N F O}

\section{Article history:}

Received 24 November 2010

Received in revised form 19 July 2011

Accepted 2 August 2011

\section{Keywords:}

Biodiversity

Ecological network

Model

Post-normal science

Integrated conservation

\begin{abstract}
A B S T R A C T
Ecological networks provide an operational methodology for the implementation of regional conservation strategy and planning that goes beyond protected area designation to integrate the spatial scale of ecological processes and social issues. However, the pertinence of ecological networks as a conservation strategy has recently provoked debate. In this paper we present a discussion of the conceptual limits of ecological network implementation in order to identify the issues which underlie the transition of models and knowledge from science to action. Our examination illustrates how a more collective and explicit management of complexity and uncertainty concerning the ecological processes which such networks supposedly integrate could greatly strengthen the links between science and policy and thereby provide for more effective spatial landscape planning. In this way, the ecological action network could be reframed not as a simple objective but rather as a means for integrated conservation policy.
\end{abstract}

(c) 2011 Elsevier GmbH. All rights reserved.

\section{Introduction}

In response to the challenge of a worldwide biodiversity crisis (Pimm, Russell, Gittleman, \& Brooks 1995), the concept of integrated conservation has been increasingly developed (Margoluis 1998; McShane 2004) to bring environmental issues to the forefront in contemporary practice (Rosenzweig 2003b). This reflects a growing recognition of the importance of global conservation issues related to the protection of natural heritage sites and the maintenance of the ecosystem functions necessary for the development and well-being of human societies (MEA 2005). However, twenty years after the concept's emergence, its implementation remains questionable. Insufficiently clear objectives, the absence of a participative approach and a short-term vision in project monitoring and evaluation have all limited the efficiency and success of integrated conservation action (Brandon \& Wells 1992). For integrated conservation to be effective, sustainable development must be incorporated not only into organisational, structural and material dimensions of a given region or territory (Laganier, Villalba, \& Zuindeau 2002) but also into its day-to-day management and the decision-making processes (Mathevet \& Mauchamp 2005; Mormont, Mougenot, \& Dasnoy 2006).

The science of conservation biology has been described as a "crisis discipline" which developed in response to the "need for action" in the 1980s (Primack 1993; Soule 1986) and ever since as a "mission-driven" discipline (Meine, Soulé, \& Noss 2006). As

\footnotetext{
* Corresponding author. Tel.: +3304676132 77; fax: +330467 410616 . E-mail addresses: raphael.mathevet@cefe.cnrs.fr, ruppert.vimal@cefe.cnrs.fr (R. Mathevet).
}

biodiversity has become a major issue in public debate (Johns 2010; Palmer et al. 2004), understanding the relationships between the concepts and ecological principles which form the framework of conservation science and the practical objectives of conservation managers and decision makers has become a key issue.

A major development in the science of conservation biology has been the recognition that biodiversity conservation must go beyond protected area boundaries to incorporate the spatial scale of ecological processes (DeFries, Hansen, Turner, Reid, \& Liu 2007; Grumbine 1994; Hansen \& DeFries 2007; Poiani, Richter, Anderson, \& Richter 2000; Thompson et al. 2011), the impact of human activities outside of protected areas (DeFries et al. 2007) and the contribution of human-dominated landscapes to conservation by reducing extinction rates (Rosenzweig 2003a).

In this context, the concept of ecological networks has, in the last decade, become an important feature of conservation planning (Jongman \& Kristiansen 2001; Jongman \& Pungetti 2004; Jongman, Kulvik, \& Kristiansen 2004; Mougenot \& Melin 2000; Opdam, Steingröver, \& Rooij 2006). In the recent landscape ecology and planning literature, the ecological network concept has indeed been promoted as "an imaginative spatial concept that helps to focus on ecologically relevant structures in the landscape and clarify arguments in priority setting" (Opdam et al. 2006, p. 329). In addition this concept has been presented as a tool which facilitates communication among actors (Jongman \& Pungetti 2004; Jongman et al. 2004). However, in the conservation biology and ecology literature there has been recent debate on the pertinence of the ecological network concept (Boitani et al. 2008).

In this paper we question the role of the representation of an ecological model in order to analyse the transition from that which raises implicit awareness of the ecological network ("the 
conceptual ecological network") to the ecological network as a tool for conservation ("the ecological action network"). We discuss how the implementation of an ecological network can provide the opportunity to revise both the conceptual and action models of an integrated conservation policy. In this way, we present the issues at stake related to the relativity and contingency of knowledge used for biodiversity conservation and discuss the need for a firm and articulated relationship between science and policy.

\section{The implicit recognition of the conceptual ecological network}

The study of the different organisational levels of biodiversity requires that the limits of ecological systems be defined, hence the recourse to the study of populations, communities and ecosystems. These representations, and the models dependent on them, are necessary for scientists to understand biodiversity and its dynamics but are not based on fixed or closed perimeters (Von Bertalanffy 1968). Indeed the open and complex character of ecological systems has long been recognised, as has the need to integrate humaninduced perturbations into the study of their dynamics (Pickett \& White 1985; Wu \& Loucks 1995). In addition, two major conceptual developments have occurred in conservation biology: first, the recognition of the need to maintain species' genetic diversity and evolutionary potential in order to ensure continued diversification (Stockwell, Hendry, \& Kinnison 2003) and second, the importance of a functional approach for the interpretation of the spatial scales of ecosystem function (Grumbine 1994, 1997) and the interactions between organisms and their environment (DeFries et al. 2007). These include the need for an ecosystem management approach to conservation in protected areas (Zorn, Stephenson, \& Grigoriev 2001 ) and the necessary integration of regional processes of colonisation and extinction into our understanding of species diversity (Ricklefs 1987) and population dynamics (Hanski 1999a, 1999b).

Over the last fifty years, agricultural intensification, urbanisation and associated land development and the construction of transport networks have given rise to an unprecedented fragmentation of natural habitats and landscapes (Stanners \& Bourdeau 1995). With the realisation that such changes in land-use represent one of the greatest contemporary threats to biodiversity (Sala et al. 2000), the study of habitat fragmentation has become a leading research theme in conservation biology (Fahrig 2003). Following its initial reference to the island models of MacArthur and Wilson (1967) and the development of the concept of meta-populations (Hanski 1999a, 1999b), the scientific community has principally addressed the role of two factors in the maintenance of species in a given area (Soule \& Simberloff 1986). First, the minimal size of a population for its viability (Shaffer 1981) which is often related to an effective surface area of habitat-the minimum dynamic area (Pickett \& Thompson 1978). Second, it has become increasingly recognised that the relationship between dispersal capacity and the spatial arrangement of habitat patches in the landscape can affect species' persistence on a regional scale (Lindenmayer et al. 2008; Wiens, Stenseth, Vanhorne, \& Ims 1993). The pertinence of ecological connectivity, be it through ecological corridors or across more or less permeable landscapes has thus become a key element in the development of the ecological network concept.

To study ecological connectivity, a great majority of studies have focused on individual species. The reductionism inherent in such a species based approach (Franklin 1993) and the inherent differences among species in their dispersal capacity and movement patterns has led to a growing appreciation of the complexity underlying any attempt to quantify the ecological connectivity of a given landscape (Lindenmayer et al. 2008; Thompson et al. 2011). In addition, many studies have relied on quantifying the structural component of habitat fragmentation (with diverse indices of fragmentation based on the surface and isolation of habitat patches) with little integration of biological information on individual, population, or species movements (Tischendorf \& Fahrig 2000a; Tischendorf \& Fahring 2000b), no doubt due to the relative simplicity of the former. There has also been much debate on the functional significance of ecological corridors among sites of high biodiversity value, mostly in terms of the ecological relevance and the fact that in many areas the landscape is not a binary landscape of natural areas and inhospitable terrain (such as in built-up areas or in highly intensified agricultural systems) but a mix of natural habitats and production landscapes that vary in their permeability of different organisms, many of whom may even depend on the matrix for their movements and life-cycle (Chetkiewicz, Clair, \& Boyce 2006; Hilty, Lidicker, \& Merelender 2006; and see below).

There has thus been growing interest in the need to protect biodiversity in the ordinary landscapes that support human activities (e.g. urban and agricultural areas) not only in terms of the need to conserve and restore habitats and their interconnectedness (Jongman \& Pungetti 2004; Jongman et al. 2004) but also for their direct contribution to biodiversity conservation. This contribution has been identified in different ways. One example concerns the reconciliation ecology of Rosenzweig (2003a) who argues how biodiversity conservation in the matrix of humandominated landscapes is now necessary to reduce extinction rates. Another example can be seen in the major role of novel ecosystems in the maintenance of functional assemblages and not just individual species (Hobbs et al. 2006). Policy should thus continue to evolve to reduce the conceptual divide between protected and unprotected areas in order to integrate the global functioning of ecological systems into landscape management and planning.

The Convention on Biological Diversity (CBD) which concluded at Rio de Janeiro on June 5th 1992 marked a major step towards integrating protected areas with their surrounding landscapes. In its Article 8 on in situ conservation the CBD invites each party to "promote environmentally sound and sustainable development in areas adjacent to protected areas with a view to furthering protection of these areas". The creation of Man and Biosphere reserves since the early 1970s (UNESCO 1996) and current moves to produce a more functional zoning of these reserves and ecological connectivity between core areas of biosphere reserves and their surroundings (UNESCO 2008) also illustrate this trend. There has thus been a significant move towards policy which integrates the notions of ecological connectivity and regional processes within landscape management and planning (Bonnin 2008). Hence, although strictly protected areas continue to be designated, protected areas' strategies have diversified to integrate human activities; as the E.U. Habitats Directive attests.

An increasing awareness of the importance of spatial ecological and evolutionary processes in biodiversity conservation strategies (Balmford, Mace, \& Ginsberg, 1998; Poiani et al. 2000; Pressey, Cowling, \& Rouget 2003; Rouget, Richardson, \& Cowling 2003; Smith, Bruford, \& Wayne 1993) has thus contributed to a change in focus from reserve designation to the elaboration of conservation management strategies for whole territories (Mougenot \& Melin 2000). The existence of a conceptual ecological network, defined by the interdependency of natural systems which contributes to their integrity on all spatial and temporal scales, has become implicitly recognised both from a scientific and strategic viewpoint.

\section{The ecological action network}

During the 1970s, the ecological network concept emerged and received special attention, notably in Europe with the adoption of a Pan-European Ecological Network (PEEN; Bonnin et al. 2007; 
Europe 1996) to maintain a coherent combination of zones representing the natural and semi-natural landscape elements. Early on, the IUCN adopted the notion of ecological corridors in its worldwide biodiversity scheme (IUCN 1980) which was later followed by its recognition of the importance of ecological networks at the World Conservation Congress in 1996. More recently, numerous initiatives have sprung up on continental, national and regional scales.

In practice, network planning is based on the "patch, matrix, corridor" model in the classic text on landscape ecology of Forman \& Godron(1986) and correspondingly strives to identify core biodiversity zones, buffer zones and connecting corridors (Jongman \& Pungetti 2004; Jongman et al. 2004). The recognition of core areas, often already delimited in the form of protected areas, is a fairly simple task. Implicit here is the need to buffer such areas from external human impacts with a surrounding buffer zone and link them to one another by ecological corridors. These structural components prevail in planning documents (Vos \& Opdam 2007), most of which attempt to identify continuums of habitat types across the landscape (Berthoud, Lebeau, \& Righetti 2004).

The ecological network concept has thus been developed for the particular context of highly human-dominated landscapes in Europe, where it has obtained unprecedented social and political success (Jongman \& Pungetti 2004; Jongman et al. 2004). Ecological networks portray an attractive and simple model for visualising biodiversity conservation on a scale that goes beyond the boundaries of protected areas and links biodiversity conservation to land-use planning (Opdam, Foppen, \& Vos 2001; Opdam et al. 2006). The representations of an ecological network, and notably the corridor, are sufficiently vague, flexible and metaphorical to win them support among, and favour their appropriation by, a large number of actors (Van der Windt \& Swart 2008). Nonetheless, this emphasis on an operational representation that focuses on a structural connectivity which supposedly allows for a more complete consideration of biodiversity, causes ecological network implementation to oversimplify complex ecological concepts (Boitani, Falcucci, Maiorano, \& Rondinini 2007).

Although the importance of connectivity for species persistence is clear in many cases (Boitani et al. 2007; Lindenmayer et al. 2008), there has been much scientific debate on the positive, negative or neutral aspects of ecological corridors (Beier \& Noss 1998; Haddad 1999; Haddad \& Baum 1999; Breininger \& Carter 2003; Crooks \& Sanjayan 2006). An important issue here which is often neglected in the debate is that corridors are only one element of the different possible ways in which connectivity is achieved (Levey, Bolker, Tewksbury, Sargent, \& Haddad 2005; Simberloff, Farr, Cox, \& Mehlman 1992; Van der Windt \& Swart 2008). Connectivity is not simply a measure of spatial separation based on patch size and distance, but a measure of the extent to which species, resources and ecological processes can move in a landscape (Lindenmayer et al. 2008; Thompson et al. 2011). These authors stress that the model suffers from its binary vision of a territory comprising favourable or detrimental zones. This approach neglects the extent to which the matrix is permeable to species movements and ecological processes. Such a model is poorly adapted to large parts of rural Europe and elsewhere, where low-intensity human activities have greatly affected the spatial organisation of biodiversity and contributed to the evolution of a heterogeneous mosaic landscape with multiple habitats and multiple usages. In a non exhaustive manner, we detail here some key points which justify this criticism.

First, the reliance of an approach based on identifying corridors as continuous elements of a particular habitat type is highly problematic since connectivity is often maintained in naturally discontinuous and variable landscapes. Indeed, for some species, what is important is connectivity among different types of habitat for different activities (foraging - nesting for example) or different stages of the life-cycle (seasonal habitats).

Second, the logic of ecological network policy is based on the idea that by connecting patches one can increase effective population size and favour the overall persistence of species in a region (Opdam et al. 2006). This may well be true in many cases; however, in some situations a primary conservation objective may be to increase the size of individual populations by reinforcement strategies because if individual populations are too small they are unlikely to export individuals. In this situation, structural connectivity will not equate to functional connectivity and arguments based on spatial cohesion will be questionable. Basically, the proposition that ecological networks provide a solution to fragmentation does not hold if individual patches are too small to export individuals.

Third, the problem with a structural description of landscape and habitat fragmentation is that isolated communities may take a long time to show the real effects of fragmentation. For example, species richness in grassland fragments has been shown to be more determined by historical patterns of landscape configuration than by the contemporary configuration of the landscape (Lindborg \& Eriksson 2004). Recommending corridors based on contemporary habitat configuration and a purported need for enhanced connectivity may thus be flawed.

Overall, the emergence of ecological networks questions the possibility of identifying a spatial set of landscape elements to define a strategy for biodiversity in its entirety. Even in some intensively human-dominated landscapes, and certainly for more rural landscapes which are maintained by extensive pastoral farming and other non-intensive agricultural practices, an ecological network is more than just a network in its true sense of interconnected nodes. We argue that the conceptual limitations described above stem from an over reliance on translating maps into processes and a rather poor and confused definition and representation of the processes such maps conceal. In addition to the traditionally recognised ecological components (core and buffer zones, corridors), the remaining landscape matrix should also be identified as having critical ecological functions (Hilty et al. 2006). The ecological network concept needs to integrate the complexity of interactions and interdependency across the landscape matrix.

\section{Systems and networks}

The distinction between the conceptual ecological network and the development of an ecological action network illustrates the difficulty of accounting for nature's complexity when it comes to action and questions the integration of complex and uncertain knowledge into conservation strategies (Cullen 1990; Hayward 2006; Moore et al. 2009). Mougenot (2003, p. 57) captured the situation all too well when she observed that in the case of ecological networks "instead of witnessing the immediate acceptance of this concept we have observed that a new debate has begun".

By definition, the conceptual ecological network does not have a material basis, nor is it perceptible. Its realisation requires first and foremost basic knowledge on the function and dynamics of ecological systems, whose complexity means that our understanding is plagued with uncertainty. Indeed, biodiversity conservation in general occurs in an uncertain world (Burgman, Lindenmayer, \& Elith 2005). The diversity of relevant systems must be considered and incorporated through a multitude of models. One has also to understand the links which give the conceptual network its coherence. The conception of ecological networks and their interpretation requires the use of a conceptual framework borrowed from systems theory, network science and philosophy. According to Dupuy (1985), if a system is defined internally by its sub-systems 
and externally by its relationships with the environment, it can be represented as a network. In contrast to a system, a network allows for communication because its structure does not have a hierarchy. Connectivity is to the network what organisation is to the system, and should be considered as "all the system's relationships which allow it to function". Consequently, the acknowledgement of a conceptual ecological network clearly demonstrates its link to interdependency and to processes. The network is the relational machine par excellence (Bressand 1995).

As discussed above, the ecological action network is based primarily on a landscape system's structural aspects, through supposedly identifiable elements such as core areas of biodiversity or ecological corridors. In addition to the single species approach which is often adopted, reductionism manifests itself in two other ways. First, understanding the action network depends exclusively on the landscape scale. Second, the representation of links between different elements (or subsystems) of an eventual landscape system is ensured by a unique model. In other words, understanding the way ecological networks operate uniquely through the "patch, corridor, matrix" model is like considering an area's social network exclusively through the physical connections which interlink different village populations (numbers and lengths of roads, etc.). But as we know, understanding social networks requires many levels of analysis (such as relations between individuals within villages) as well as understanding alternative means of contact (such as the telecommunications network).

This change in ecological action networking is linked to analogies made possible by the polysemy of the network concept (Bakis 1993). The ecological action network has seen much success because it has been often rendered analogous to other better known networks which are characteristic of our society, such as transport or communication networks, (Keulartz 2007; Van der Windt \& Swart 2008). As Musso (1999) points out: "from being natural, the network becomes artificial, (.) the engineer conceives and constructs it while the doctor observes".

\section{Modelling and action}

The implementation of conservation policies reflects the nature of their supporting knowledge and highlights the question of knowledge sharing between scientists and field managers and between different disciplines. Scientists use models for specific purposes in order to test predefined hypotheses. They make the choice of pertinent models and collectively judge the contingency and reductionism they engender. The "patch, corridor, matrix" model was thus formalised with a specific aim: to establish a link between the spatial organisation of landscape elements and biodiversity dynamics. However, the ecological network model has a different meaning in the scientific community, where it is used to test hypotheses relative to the functioning of populations in a landscape, compared to in a local society, where it becomes the unique representation of the complexity of ecological systems in a given area. As discussed above, the spatial arrangement of landscape elements is thus often used as a basis to establish a strong link between structure and function (Bruter 1976). This underlines the issue of scientific simplification and of the significance of its use in land planning. Indeed, the model's transmission is socially situated and thus dependent on a socio-political context for the development of conservation policies.

A model can be perceived as useful for scientists to test hypotheses and to gradually refine knowledge (Vinck 1999). In much the same way, a model is a means to facilitate interactions and the transfer of knowledge between stakeholders and for reflection on the political and technical complexity of decision-making (ComMod 2009). We therefore propose a shift from the ecological action network as an objective towards a network which more clearly represents a means of introducing governance and collective thought and action for land development and conservation. This shift underlines the debate surrounding the representations and conversion modes necessary for the elaboration of a social compromise capable of incorporating the range of knowledge on the mechanisms of socio-ecological systems. In this way a model will at least indicate the importance of linking science and sociopolitics in order to resolve ecological problems (Latour 1999), the first step towards an indispensably co-constructed and integrated conservation policy.

\section{Science-society interactions: integrated conservation as post-normal science}

Ecological processes and biodiversity conservation issues are no longer defined simply in terms of natural and factual realities; they also include the plurality of social realities in which scientists work and which are continuously shaped by new scientific developments and technological progress. Within the context of ecological network development, there is uncertainty on what to do and a greater awareness of the place of people in knowledge production (Mougenot \& Melin 2000). During the last decade, in most developed countries, science has been confronted with a huge decline in its cognitive authority, social influence and public confidence. Science and technology have been progressively separated from the public arena and their place occupied by environmental and conservation NGOs (Nowotny, Scott, \& Gibbons 2001). With the ever-growing acceptance that non-scientists represent sources of expertise, it has become increasing important to share and discuss scientific and non-scientific expertise in a legitimate social process (Callon et al. 2001). Indeed, on an operational level, conservation science depends increasingly on social consensus and thus on the action plan itself, hence the tight interrelationship between knowledge and dialogue (Habermas 1987).

Confronted with uncertainty, improving the quality of decisions and freeing them from strictly scientific and technical criteria have become crucial elements in the science-policy interface. Here, the notion of post-normality (Funtowicz \& Ravetz 1993) implicates stakeholders in a scheme for the elaboration of decisions and knowledge as well as of the evaluation of the quality of both knowledge and procedures (Francis \& Goodman 2010). By considering the plurality of the legitimacy of action, the simultaneous construction of both knowledge and action is encouraged in a pragmatic way (Funtowicz \& Ravetz 1993; Light 2003). A principal advantage of this approach lies in its social robustness; it contains a pluralistic plan that integrates diverse opinions and uses mediation tools and techniques to facilitate exchange among science, society and policy (ComMod 2006). However, it is essential here that all participants recognise that they contribute to a common goal (Latour 1997; Stengers 2009) and that they are on equal standing (Habermas 1987). This means developing the basic respect of diverse opinions by developing the power to think, imagine and learn more about each other (Stengers 2002, 2009).

One of the key issues frequently raised by conservation scientists in relation to post-normal science is that it may implicitly devalue the professional opinions of scientists by suggesting that all actors are equal and all viewpoints valid. This recurrent opinion relies on a fundamental misunderstanding on how the contextualisation of conservation sciences occurs. Differences between scientists and non-scientists remain in terms of their competence and skills. The cynical postures of some scientists are common pitfalls, and other failures on interdisciplinarity, action-research, participatory processes and community-based management are well studied and identified (Liu 1997; Reed 2008). As Isabelle 
Stengers has argued, we have to go beyond the participatory injunction and to develop a process that creates an "operating context" that allows us to "make common cause". Here, it is necessary to go beyond a participatory approach to put stakeholders in a position where they can understand, evaluate and synthesise available knowledge in order to confront it with the realities of their territory and to allow them to co-produce the final decision. Based on scientific knowledge, the process should create a new type of knowledge, one that is pragmatic, local, and ready for action as well as being validated and evaluated by the group of actors. Post-normal, contextualised and mode 2 science thus do not reject normal science (De Marchi, Funtowicz, \& Guimaraes Pereira 2001; Funtowicz \& Ravetz 1993, 1994; Funtowicz, Ravetz, Shepherd, \& Wilkinson 2000; Nowotny et al. 2001; Van der Windt \& Swart 2008).

Ecological network strategies thus invite us to experiment a fundamental reconstruction of the relationships between disciplines, scientists, administrations and stakeholders at the scales of regions and territories. There are three main critical points which remain at stake here. First, there is still a need to develop scientific and public knowledge in a way which allows for more interactive feedbacks from society to science and vice versa. Second, it is necessary to give full appreciation and commitment to the temporal processes underlying ecological network function. Third, a transparent and participative process with the involvement of a variety of stakeholders in a trust building and capacity building process remains to be more fully developed.

Finally, we argue that the process of making maps remains a major issue to ensure a reliable and socially robust strategy. However, to allow the shift from the action network as a finality to the network as a means for integrated conservation, the scientific process should not target a precise spatial identification of the network as suggested by the traditional ecological network model, but instead strive towards spatial representations which allow stakeholders to visually understand which biodiversity elements and which human pressures are involved, and how to priorities for action in space and time can be identified. Thus, through the mapping process, the role of the scientists in the participative approach is not to identify the ecological network and where and how to protect it, but more to facilitate a social debate concerning its representation.

\section{Conclusion}

Traditionally public policy has distinguished protected areas from production landscapes. However, the recognition of the functional ecological interdependency of such spaces and the integration of the true spatial scale of ecological functions into land-use planning has been increasing advocated. Indeed, conserving landscapes of ordinary biodiversity has become a key issue, to which ecological networks can now greatly contribute. The ecological network concept advocates the reconsideration of the distinction between nature considered to have a value for conservation and more banal "ordinary" nature. This has required the integration of the aims, perceptions and values of a much larger number of actors (Mougenot 2003) and thus the need to develop more intricate links between economic development, ecology and society (Rosenzweig 2003a).

Although the generalisation of the "patch, corridor, matrix" model has facilitated its social appropriation, we argue that the real challenge is to plan the collective construction of a shared vision of nature so that the ecological action network can become a means of acting on the conceptual ecological network. It is paramount to recognise here that an overly important role of a unique spatial (mapping) representation of the ecological network concept - which as we discuss above is often adopted - will only reinforce the perception of a human-dominated influence on the world and on nature, where human societies remain distinct from the natural world. It is necessary to go beyond this simple cartographic representation of ecological networks to encompass their true function and the role of human activities within the network. Although the financing of an animal passageway across a major infrastructure or contracts for late harvests can be punctually useful for biodiversity conservation and ecological connectivity across the landscape, we believe that the passage from the concept of ecological networks to actions for their elaboration should integrate an approach which facilitates the reconciliation of human societies and nature.

We now need an approach based on collective learning for social change and a pragmatic constructivist position to clearly identify the input of stakeholders. By advocating the coexistence of humans and nature, the ecological network concept could allow for a tighter integration between science and decision making which provides for a more complete inclusion of conservation objectives as part of societies' goals and values. The development of ecological network strategies for biodiversity conservation thus necessitates thought on the place of humans in nature and the need to construct a new positive relationship between man and nature. We argue elsewhere that this relationship may be identified in the form of ecological solidarity (Mathevet et al. 2010; Thompson et al. 2011). Such a conception of ecological networks would be a major step towards an ecosystemic and eco-centric view for biodiversity conservation (Callicott 1999; Larrère \& Larrère 1997; Léopold 1949).

The extent to which ecological networks are succeeding in securing the desired compatibility between biodiversity conservation and resource use is not yet clear. By focussing more on the needs of local populations than on economic growth, by placing the critique of science and the co-construction of projects at the heart of the process, we argue that participative territory development could offer a sustainable alternative to policy which has prevailed until now. These developments would contribute to placing ecological networks clearly on the map of effective conservation strategies.

\section{Acknowledgements}

We thank Elisabeth Salverda for her help with the English version and Lenore Fahrig for her advice on a preliminary version of the manuscript. This work was funded by the "Agence Nationale de la Recherche" (contract 05-BDIV-014, ABIME), the EU (contract 226852, SCALES) and the Languedoc-Roussillon Regional Council.

\section{References}

Bakis, H., 1993. Les réseaux et leurs enjeux sociaux, “Que sais-je?" Paris, France.

Balmford, A., Mace, G. M., \& Ginsberg, J. R. (1998). The challenges to conservation in a changing world: Putting processes on the map. Conservation Biology Series (Cambridge), 1, 1-28.

Beier, P., \& Noss, R. F. (1998). Do habitat corridors provide connectivity? Conservation Biology, 12(6), 1241-1252.

Berthoud, G., Lebeau, R. P., \& Righetti, A. (2004). Réseau écologique national (REN). Rapport final. Berne Office Fédéral de l'Environnement, des Forêts et du Paysage.

Boitani, L., Falcucci, A., Maiorano, L., \& Rondinini, C. (2007). Ecological networks as conceptual frameworks or operational tools in conservation. Conservation Biology, 21(6), 1414-1422.

Boitani, L., Sinibaldi, I., Corsi, F., De Biase, A., Carranza, I. D., Ravagli, M., et al. (2008). Distribution of medium- to large-sized African mammals based on habitat suitability models. Biodiversity and Conservation, 17(3), 605-621.

Bonnin, M. (2008). Les corridors écologiques: vers un troisième temps du droit de la conservation de la nature? Paris, France: L'Harmattan.

Bonnin, M., Bruszik, A., Delbaere, B., Lethier, H., Richard, D., Rientjes, S., et al. (2007). The pan-European ecological network: Taking stock. Strasbourg, France: Conseil de l'Europe.

Brandon, K. E., \& Wells, M. (1992). Planning for people and parks-Design dilemmas. World Development, 20(4), 557-570. 
Breininger, D. R., \& Carter, G. M. (2003). Territory quality transitions and sourcesink dynamics in a Florida Scrub-Jay population. Ecological Applications, 13(2), 516-529.

Bressand, A., \& Distler, C. (1995). La planète relationnelle. Paris, France: Flammarion. Bruter, C. P. (1976). Topologie et perception, t.2: Aspects neurophysiologiques. Paris, France: Doin \& Maloine.

Burgman, M. A., Lindenmayer, D. B., \& Elith, J. (2005). Managing landscapes for conservation under uncertainty. Ecology, 86, 2007-2017.

Callicott, J. B. (1999). Beyond the land ethic, more essays on environmental philosophy. New York, USA: State University of New York Press.

Callon, M., Lascoumes, P., \& Barthe, Y., 2001. Agir dans un monde incertain. Essai sur la démocratie technique, Le Seuil, Paris, France.

Chetkiewicz, C. L. B., Clair, C. C. S., \& Boyce, M. S. (2006). Corridors for conservation: Integrating pattern and process. Annual Review of Ecology Evolution and Systematics, 37, 317-342.

ComMod. (2006). Modélisation d'accompagnement. In F. Amblard, \& D. Phan (Eds.), Modélisation et simulation multi-agents: applications aux sciences de l'homme et de la société. Londres, UK: Hermes Sciences.

ComMod. (2009). La posture d'accompagnement des processus de prise de décision: les références et les questions transdisciplinaires. In D. Hervé, \& F. Laloë (Eds.), Modélisation de l'environnement: entre natures et sociétés. Paris, France: Quae, NSS-Dialogues, collection Indisciplines.

Crooks, K. R., \& Sanjayan, M. (2006). Connectivity conservation. New York, NY, USA: Cambridge University Press.

Cullen, P. (1990). The turbulent boundary between water science and water management. Freshw. Biol., 24(1), 201-209.

De Marchi, B., Funtowicz, S., \& Guimaraes Pereira, A. (2001). From the right to be informed to the right to participate: Responding to the evolution of the European legislation with ICT. International Journal of Environment and Pollution, 15(1), $1-21$.

DeFries, R., Hansen, A., Turner, B. L., Reid, R., \& Liu, J. G. (2007). Land use change around protected areas: Management to balance human needs and ecological function. Ecological Applications, 17(4), 1031-1038.

Dupuy, G. (1985). Systèmes, réseaux et territoires. Principes de réseautique territoriale. Paris, France: Presses de l'Ecole nationale des ponts et chaussées.

Europe, 1996. The Pan-European Biological and Landscape Diversity Strategy, a vision for Europe's Natural Heritage, Council of Europe, UNEP, ECNC.

Fahrig, L. (2003). Effects of habitat fragmentation on biodiversity. Annual Reviews of Ecology, Evolution and Systematics, 34, 487-515.

Forman, R. T. T., \& Godron, M. (1986). Landscape ecology. New York, NY, USA: John Wiley.

Francis, R. A., \& Goodman, M. K. (2010). Post-normal science and the art of nature conservation. Journal for Nature Conservation, 18(2), 89-105.

Franklin, J. F. (1993). Preserving biodiversity-species. Ecosystems, or Landscapes. Ecological Applications, 3(2), 202-205.

Funtowicz, S., Ravetz, J. R., Shepherd, I., \& Wilkinson, D. (2000). Science and governance in the European union. Science and Public Policy, 27(5), 327-336.

Funtowicz, S. O., \& Ravetz, J. R. (1993). Science for the post-normal age. Futures, 25, 739-755.

Funtowicz, S. O., \& Ravetz, J. R. (1994). The worth of a songbird: Ecological economics as a post-normal science. Ecological Economics, 10, 197-207.

Grumbine, R. E. (1994). What is ecosystem management. Conservation Biology, 8(1), $27-38$.

Grumbine, R. E. (1997). Reflections on "what is ecosystem management?". Conservation Biology, 11(1), 41-47.

Habermas, J. (1987). Théorie de l'agir communicationnel. Paris, France: Fayard

Haddad, N. M. (1999). Corridor and distance effects on interpatch movements: A landscape experiment with butterflies. Ecological Applications, 9(2), 612-622.

Haddad, N. M., \& Baum, K. A. (1999). An experimental test of corridor effects on butterfly densities. Ecological Applications, 9(2), 623-633.

Hansen, A. J., \& DeFries, R. (2007). Ecological mechanisms linking protected areas to surrounding lands. Ecological Applications, 17(4), 974-988.

Hanski, I. A. (1999a). Habitat connectivity, habitat continuity and metapopulations in dynamic landscapes. Oikos, 87, 209-219.

Hanski, I. A. (1999b). Metapopulation ecology. Oxford, UK: Oxford University Press.

Hayward, S. F. (2006). Environmental science and public policy. Social Research, 73(3), 891-914.

Hilty, J. A., Lidicker, W. Z. J., \& Merelender, A. M. (2006). Corridor ecology. The science and practice of linking landscapes for biodiversity conservation. Washington, DC: Island Press.

Hobbs, R. J., Arico, S., Aronson, J., Baron, J. S., Bridgewater, P., Cramer, V. A., et al. (2006). Novel ecosystems: Theoretical and management aspects of the new ecological world order. Global Ecology and Biogeography, 15, 1-7.

IUCN, 1980. World conservation strategy. Living Resource Conservation for Sustainable Development International Union for Conservation of Nature and Natural Resources.

Johns, D. (2010). Adapting human societies to conservation. Conservation Biology, 23, 641-643.

Jongman, R., \& Pungetti, G. (2004). Ecological networks and greenways: Concept, design, implementation. [Cambridge studies in landscape ecology.] i-xxi, 1-345.

Jongman, R. H. G., \& Kristiansen, I. (2001). National and regional approaches for ecological networks in Europe. Council of Europe Nature and Environment Series, $110,1-86$.

Jongman, R. H. G., Kulvik, M., \& Kristiansen, I. (2004). European ecological networks and greenways. Landscape and Urban Planning, 68(2-3), 305-319.

Keulartz, J. (2007). Using metaphors in restoring nature. Nature and Culture, 2, 27-48.
Laganier, R., Villalba, B., \& Zuindeau, B. (2002). Le développement durable face au territoire: éléments pour une recherche pluridisciplinaire.

Larrère, C., \& Larrère, R. (1997). Du bon usage de la nature. Paris, France: Aubier.

Latour, B. (1997). Nous n'avons jamais été modernes. Essai d'anthropologie symétrique. Paris, France: La Découverte.

Latour, B. (1999). Les politiques de la nature. Comment faire entrer les sciences en démocratie. Paris, France: Editions la Découverte.

Léopold, A. (1949). Almanach d'un comté des sables. Paris, France: Aubier.

Levey, D. J., Bolker, B. M., Tewksbury, J. J., Sargent, S., \& Haddad, N. M. (2005). Effect of landscape corridors on seed dispersal by birds. Science, 5731(309), 146-148.

Light, A. (2003). The case for practical pluralism. In A. Light, \& H. Rolston (Eds.) Environmental ethics, an anthology. Oxford, UK: Blackwell.

Lindborg, R., \& Eriksson, O. (2004). Historical landscape connectivity affects present plant species diversity. Ecology, 85, 1840-1845.

Lindenmayer, D., Hobbs, R. J., Montague-Drake, R., Alexandra, J., Bennett, A. Burgman, M., et al. (2008). A checklist for ecological management of landscapes for conservation. Ecology Letters, 11(1), 78-91.

Liu, M. (1997). Fondements et pratiques de la recherche-action. Paris, France: L'Harmattan.

MacArthur, R. H., \& Wilson, E. O. (1967). The theory of island biogeography. Princeton, NJ, USA: Princeton University Press.

Margoluis, R., \& Salafsky, N. (1998). Measures of success: Designing, managing, and monitoring conservation and development projects. Washington, W, USA: Island Press.

Mathevet, R., \& Mauchamp, A. (2005). Evidence-based conservation: Dealing with social issues. Trends in Ecology E Evolution, 20(8), 422-423.

Mathevet, R., Thompson, J., Delanoë, O., Cheylan, M., Gil-Fourrier, C., \& Bonnin, M. (2010). La solidarité écologique: un nouveau concept pour la gestion intégrée des parcs nationaux et des territoires. Natures Sciences Sociétés, 18, 424-433.

McShane, T. O., \& Wells, M. P. (2004). Getting biodiversity projects to work: Towards more effective conservation and development. New York, NY, USA: Columbia University Press.

MEA. (2005). Ecosystems and human well-being. Washington Covelo London, USA UK: Island Press.

Meine, C., Soulé, M. E., \& Noss, R. F. (2006). "A mission-driven discipline”: The growth of conservation biology. Conservatin Biology, 20, 631-651.

Moore, S., Wallington, T., Hobbs, R., Ehrlich, P., Holling, C., Levin, S., et al. (2009). Diversity in current ecological thinking: Implications for environmental management. Environmental Management, 43(1), 17-27.

Mormont, M., Mougenot, C., \& Dasnoy, C. (2006). La participation composante du développement durable: quatre études de cas. Vertigo, 7, 2.

Mougenot, C. (2003). Prendre soin de la nature ordinaire. Paris, France: Editions de la Maison des sciences de l'homme.

Mougenot, C., \& Melin, E. (2000). Entre science et action: le concept de réseau écologique. Natures Sciences Sociétés, 8(3), 20-30.

Musso, P. (1999). La symbolique du réseau. Quarderni, 38, 69-98.

Nowotny, H., Scott, P., \& Gibbons, M. (2001). Re-thinking science. Knowledge and the public in an age of uncertainty. Cambridge, UK: Polity Press.

Opdam, P., Foppen, R., \& Vos, C. (2001). Bridging the gap between ecology and spatial planning in landscape ecology. Landscape Ecology, 16(8), 767-779.

Opdam, P., Steingröver, E., \& Rooij, S. V. (2006). Ecological networks: A spatial concept for multi-actor planning of sustainable landscapes. Landscape and Urban Planning, 75(3-4), 322-332.

Palmer, M., Bernhardt, E., Chornesky, E., Collins, S., Dobson, A., Duke, C., et al. (2004) Ecology for a crowded planet. Science, 304, 1251-1252.

Pickett, S. T. A., \& Thompson, J. N. (1978). Patch dynamics and design of nature reserves. Biological Conservation, 13(1), 27-37.

Pickett, S. T. A., \& White, P. S. (1985). The ecology of natural disturbance and patch dynamics. New York, NY USA: Academic Press.

Pimm, S. L., Russell, G. J., Gittleman, J. L., \& Brooks, T. M. (1995). The future of biodiversity. Science, 5222(269), 347-350.

Poiani, K. A., Richter, B. D., Anderson, M. G., \& Richter, H. E. (2000). Biodiversity conservation at multiple scales: Functional sites, landscapes, and networks. Bioscience, 50(2), 133-146.

Pressey, R. L., Cowling, R. M., \& Rouget, M. (2003). Formulating conservation targets for biodiversity pattern and process in the Cape Floristic Region, South Africa. Biological Conservation, 112(1-2), 99-127.

Primack, R. B. (1993). Essentials of conservation biology. Sunderland, MA, USA: Sinauer Associates.

Reed, M. S. (2008). Stakeholder participation for environmental management: A literature review. Biological Conservation, 141(10), 2417-2431.

Ricklefs, R. E. (1987). Community diversity: Relative roles of local and regional processes. Science, 235, 167-171.

Rosenzweig, M. L. (2003a). Reconciliation ecology and the future of species diversity Oryx, 37(2), 194-205.

Rosenzweig, M. L. (2003b). Win-Win Ecology. How the earth's species can survive in the midst of human enterprise. New York, NY, USA: Oxford University Press.

Rouget, M., Richardson, D. M., \& Cowling, R. M. (2003). The current configuration of protected areas in the Cape Floristic Region South Africa-Reservation bias and representation of biodiversity patterns and processes. Biological Conservation 112(1-2), 129-145.

Sala, O. E., Chapin, F. S., Armesto, J. J., Berlow, E., Bloomfield, J., Dirzo, R., et al. (2000) Biodiversity-Global biodiversity scenarios for the year 2100. Science, 287(5459), 1770-1774.

Shaffer, M. L. (1981). Minimum population sizes for species conservation. BioScience $31,131-134$ 
Simberloff, D., Farr, J. A., Cox, J., \& Mehlman, D. W. (1992). Movement corridors-conservation bargains or poor investments. Conservation Biology, 6(4), 493-504.

Smith, T. B., Bruford, M. W., \& Wayne, R. K. (1993). The preservation of process: the missing element of conservation programs. Biodiversity Letters, 1(6), 164-167.

Soule, M. E. (1986). Conservation biology-The science of scarcity and diversity. Sunderland, MA, USA: Sinauer Associates.

Soulé, M. E., \& Simberloff, D. (1986). What do genetics and ecology tell us about the design of nature reserves? Biological Conservation, 35, 19-40.

Stanners, D., \& Bourdeau, P. (1995). Europe's environment: The Dobris assessment. Copenhagen, Denmark: European Environmental Agency.

Stengers, I. (2002). Sciences et pouvoirs. Paris, France: La démocratie face à la technoscience, La Découverte.

Stengers, I. (2009). Au temps des catastrophes. Paris, France: Résister à la barbarie qui vient, La Découverte.

Stockwell, C. A., Hendry, A. P., \& Kinnison, M. T. (2003). Contemporary evolution meets conservation biology. Trends in Ecology and Evolution, 18, 94-101.

Thompson, J. D., Mathevet, R., Delanoë, O., Gil-Fourrier, C., Bonnin, M., \& Cheylan, M. (2011). Ecological solidarity as a conceptual tool for rethinking ecological and social interdependence in conservation policy for protected areas and their surrounding landscape. Comptes Rendus de l'Académie des Science, Biologies, 334, 412-419.

Tischendorf, L., \& Fahrig, L. (2000a). How should we measure landscape connectivity? Landscape Ecology, 15(7), 633-641.
Tischendorf, L., \& Fahring, L. (2000b). On the usage and measurement of landscape connectivity. Oikos, 90(1), 7-19.

UNESCO, 1996. Biosphere reserves. The Seville strategy \& the statutory framework of the World network, Paris.

UNESCO, 2008. Madrid Action Plan for Biosphere Reserves (2008-2013).

Van der Windt, H. J., \& Swart, J. A. A. (2008). Ecological corridors, connecting science and politics: The case of the Green River in the Netherlands. Journal of Applied Ecology, 45, 124-132.

Vinck, D. (1999). Ingénieurs au quotidien. Ethnographie de l'activité de conception et d'innovation. Grenoble, France: Presses Universitaires de Grenoble.

Von Bertalanffy, L. (1968). General System Theory: Foundations, Developments, Applications. New York, NY, USA: Braziller.

Vos, C. C., Opdam, P., Steingröver, E. G., \& R., R. (2007). Transferring ecological knowledge to landscape planning: A design method for robust corridors. In J. Wu, \& R. Hobbs (Eds.), Key topics in landscape ecology. Cambridge, UK: Cambridge University Press.

Wiens, J. A., Stenseth, N. C., Vanhorne, B., \& Ims, R. A. (1993). Ecological mechanisms and landscape ecology. Oikos, 66(3), 369-380.

Wu, J., \& Loucks, O. L. (1995). From balance of nature to hierarchical patch dynamics: A paradigm shift in ecology. The Quarterly Review of Biology, 70, 439-466.

Zorn, P., Stephenson, W., \& Grigoriev, P. (2001). An ecosystem management program and assessment process for Ontario National Parks. Conservation Biology, $15,353-362$. 